\title{
Program and patient characteristics for the United States Expanded Access Program to COVID-19 convalescent plasma
}

\author{
Running Title: Expanded access to COVID-19 convalescent plasma
}

Jonathon W. Senefeld ${ }^{1 \dagger}$, Ph.D., Patrick W. Johnson ${ }^{\dagger \dagger}$, B.S., Katie L. Kunze ${ }^{3 \dagger}$, Ph.D., Noud van Helmond $^{4 \dagger}$, M.D., Stephen A. Klassen1, Ph.D., Chad C. Wiggins ${ }^{1}$, Ph.D., Katelyn A. Bruno ${ }^{5}$, Ph.D., Michael A. Golafshar', M.S., Molly M. Petersen ${ }^{3}$, B.S., Matthew R. Buras ${ }^{3}$, M.S., Allan M. Klompas ${ }^{1}$, M.B., B.Ch., B.A.O., Matthew A. Sexton'1, M.D., Juan C. Diaz Soto', M.D., Sarah E. Baker $^{1}$, Ph.D., John R.A. Shepherd ${ }^{1}$, M.D., Nicole C. Verdun ${ }^{6}$, M.D., Peter Marks ${ }^{6}$, M.D., Ph.D., Camille M. van Buskirk', M.D., Jeffrey L. Winters ${ }^{7}$, M.D., James R. Stubbs ${ }^{7}$, M.D., Robert F. Rea ${ }^{8}$, M.D, Vitaly Herasevich ${ }^{1}$, M.D., Ph.D., Emily R. Whelan ${ }^{5}$, B.S., Andrew J. Clayburn ${ }^{1}$, B.S., Kathryn F. Larson ${ }^{8}$, M.D., Juan G. Ripoll', M.D., Kylie J. Andersen ${ }^{1}$, B.S., Matthew N.P. Vogt ${ }^{1}$, M.D., Joshua J. Dennis ${ }^{1}$, B.S., Riley J. Regimbal' ${ }^{1}$, B.S., Philippe R. Bauer ${ }^{9}$, M.D., Ph.D., Janis E. Blair ${ }^{10}$, M.D., Katherine Wright ${ }^{11}$, BA, Joel T. Greenshields ${ }^{12}$, MS, Nigel S. Paneth ${ }^{13 \dagger}$, M.D., M.P.H., DeLisa Fairweather ${ }^{5 \dagger}$, Ph.D., R. Scott Wright ${ }^{8,14 \dagger}$, M.D., Arturo Casadevall ${ }^{15 \dagger}$, M.D., Ph.D., Rickey E. Carter ${ }^{2 \dagger}$, Ph.D., Michael J. Joyner ${ }^{1{ }^{\star}}$, M.D.

\section{AFFILIATIONS}

1Department of Anesthesiology and Perioperative Medicine, Mayo Clinic, Rochester, Minnesota, United States of America

${ }^{2}$ Department of Health Sciences Research, Mayo Clinic, Jacksonville, Florida, United States of America ${ }^{3}$ Department of Health Sciences Research, Mayo Clinic, Scottsdale, Arizona, United States of America ${ }^{4}$ Department of Anesthesiology, Cooper Medical School of Rowan University, Cooper University Health Care, Camden, New Jersey, United States of America

${ }^{5}$ Department of Cardiovascular Medicine, Mayo Clinic, Jacksonville, Florida, United States of America ${ }^{6}$ Center for Biologics Evaluation and Research, U.S. Food and Drug Administration, Silver Spring, Maryland, United States of America

${ }^{7}$ Department of Laboratory Medicine and Pathology, Mayo Clinic, Rochester, Minnesota, United States of America

${ }^{8}$ Department of Cardiovascular Medicine, Mayo Clinic, Rochester, Minnesota, United States of America ${ }^{9}$ Department of Internal Medicine, Division of Pulmonary and Critical Care, Mayo Clinic, Rochester, Minnesota, United States of America

${ }^{10}$ Department of Internal Medicine, Division of Infectious Diseases, Mayo Clinic, Phoenix, Arizona, United States of America

${ }^{11}$ School of Sustainability, Arizona State University, Tempe, Arizona, United States of America

${ }^{12}$ Department of Kinesiology, Indiana University, Bloomington, Indiana, United States of America

${ }^{13}$ Departments of Epidemiology and Biostatistics and Pediatrics and Human Development, College of Human Medicine, Michigan State University, East Lansing, Michigan, United States of America

${ }^{14}$ Department of Human Research Protection Program, Mayo Clinic, Rochester, Minnesota, United States of America

${ }^{15}$ Department of Molecular Microbiology and Immunology, Johns Hopkins Bloomberg School of Public Health, Baltimore, Maryland, United States of America

tThese authors have contributed equally to this work. 
2 Background

3 The United States (US) Expanded Access Program (EAP) to COVID-19 convalescent

4 plasma was initiated in response to the rapid spread of severe acute respiratory syndrome coronavirus 2 (SARS-CoV-2), the causative agent of coronavirus disease-2019 (COVID19). While randomized clinical trials were in various stages of development and enrollment, there was an urgent need for widespread access to potential therapeutic agents particularly for vulnerable racial and ethnic minority populations who were

9 disproportionately affected by the pandemic. The objective of this study is to report on the demographic, geographic, and chronological access to COVID-19 convalescent plasma

11 in the US via the EAP.

\section{Methods and findings}

Mayo Clinic served as the central IRB for all participating facilities and any US physician could participate as local physician-principal investigator. Registration occurred through the EAP central website. Blood banks rapidly developed logistics to provide convalescent plasma to hospitalized patients with COVID-19. Demographic and clinical characteristics

17 of all enrolled patients in the EAP were summarized. Temporal trends in access to COVID-19 convalescent plasma were investigated by comparing daily and weekly changes in EAP enrollment in response to changes in infection rate on a state level. Geographical analyses on access to convalescent plasma included assessing EAP

21 enrollment in all national hospital referral regions as well as assessing enrollment in

22 metropolitan and less populated areas which did not have access to COVID-19 clinical 23 trials. 
medRxiv preprint doi: https://doi.org/10.1101/2021.04.08.21255115; this version posted April 11, 2021. The copyright holder for this preprint (which was not certified by peer review) is the author/funder, who has granted medRxiv a license to display the preprint in perpetuity.

All rights reserved. No reuse allowed without permission.

24 From April 3 to August 23, 2020, 105,717 hospitalized patients with severe or life-

25 threatening COVID-19 were enrolled in the EAP. A majority of patients were older than

60 years of age $(57.8 \%)$, male $(58.4 \%)$, and overweight or obese $(83.8 \%)$. There was

27 substantial inclusion of minorities and underserved populations, including $46.4 \%$ of patients with a race other than White, and $37.2 \%$ of patients were of Hispanic ethnicity.

Severe or life-threatening COVID-19 was present in $61.8 \%$ of patients and $18.9 \%$ of patients were mechanically ventilated at time of convalescent plasma infusion.

31 Chronologically and geographically, increases in enrollment in the EAP closely followed

32 confirmed infections across all 50 states. Nearly all national hospital referral regions enrolled patients in the EAP, including both in metropolitan and less populated areas.

\section{Conclusions}

35 The EAP successfully provided widespread access to COVID-19 convalescent plasma in all 50 states, including for underserved racial and ethnic minority populations. The

37 efficient study design of the EAP may serve as an example framework for future efforts when broad access to a treatment is needed in response to a dynamic disease affecting demographic groups and areas historically underrepresented in clinical studies. 
medRxiv preprint doi: https://doi.org/10.1101/2021.04.08.21255115; this version posted April 11, 2021. The copyright holder for this preprint (which was not certified by peer review) is the author/funder, who has granted medRxiv a license to display the preprint in perpetuity.

\section{Introduction}

41 Severe acute respiratory syndrome coronavirus 2 (SARS-CoV-2), the causative agent of

42 the coronavirus disease 2019 (COVID-19), spread rapidly across the United States (US)

43 after confirmation of the first case of COVID-19 in the US in December 2019 and January

442020 [1]. By March of 2020 in the Northeast region of the US, community transmission was occurring in major metropolitan areas and hospitals became overwhelmed with admissions for severe or life-threating COVID-19 [1]. Although most infected persons

47 have few or no symptoms despite high SARS-CoV-2 viral loads [2], a smaller group of 48 persons develop hypoxemia and severe COVID-19 leading to hospitalization with supplemental oxygen support [3]. Severe cases of COVID-19 can lead to respiratory failure, which is among the leading causes of death in persons with COVID-19 [4].

51 The cornerstone of treatment for patients with COVID-19 was symptomatic and

52 supportive management [5]. Because there was a dearth of evidence supporting the

53 efficacy of COVID-19 therapeutic strategies during the early stages of this public health 54 emergency, immunomodulatory agents and antivirals, represented promising strategies

55 that were anticipated to provide benefit to patients with COVID-19 [6, 7]. Passive 56 immunotherapy using convalescent plasma or serum had been used previously to treat

57 acute respiratory tract infections [8-10], including severe acute respiratory syndrome 58 coronavirus 1 infection (SARS-CoV-1) [11], and early studies suggested potential efficacy 59 of convalescent plasma in the treatment of COVID-19 [12-14].

60 In late March and early April of 2020, COVID-19 convalescent plasma began to be 61 administered to patients under single-patient emergency investigational new drug (eIND) 
medRxiv preprint doi: https://doi.org/10.1101/2021.04.08.21255115; this version posted April 11, 2021. The copyright holder for this preprint (which was not certified by peer review) is the author/funder, who has granted medRxiv a license to display the preprint in perpetuity.

All rights reserved. No reuse allowed without permission.

62 applications while randomized clinical trials of COVID-19 convalescent plasma were in various stages of development and enrollment. For example, one institution in New York City had 45 eIND applications submitted to and approved by the US Food and Drug Administration (FDA) in a two-week period in late March 2020 [15]. The single-patient eIND application process requires substantial administrative support from local

67 institutions and the US FDA and limits widespread and high-volume access to convalescent plasma, particularly for underserved and racial and ethnic minority populations, who were disproportionately affected by the COVID-19 pandemic [16, 17]. Additionally, clinical trials often have inclusion criteria that are restricted to a specific geographical region or disease status (e.g. hospitalized, but not severe patients) and have exclusion criteria (e.g. prisoners or recipients of solid organ transplant). Thus, inherently, more traditional regulatory pathways for obtaining access to COVID-19 convalescent plasma (eIND or clinical trials) result in limited access to convalescent plasma and may potentially limit the ability to comprehensively study the safety of convalescent plasma for the treatment of COVID-19.

77 To provide access to a COVID-19 treatment and provide a framework for standardized safety data collection, Mayo Clinic initiated the Expanded Access Program (EAP) for COVID-19 convalescent plasma. The primary objective of the EAP was to provide access to convalescent plasma for hospitalized patients in the US with severe or life-threatening

81 COVID-19 [18]. The EAP started as a national registry approved to enroll 5,000 patients,

82 but due to a national demand for COVID-19 plasma, enrollment goals were extended in collaboration with the US Food and Drug Administration (FDA) and the Biomedical

84 Advanced Research and Development Authority (BARDA) with the aim for the EAP to 
medRxiv preprint doi: https://doi.org/10.1101/2021.04.08.21255115; this version posted April 11, 2021. The copyright holder for this preprint (which was not certified by peer review) is the author/funder, who has granted medRxiv a license to display the preprint in perpetuity.

All rights reserved. No reuse allowed without permission.

85 become a broad national program obviating the need for individual patient INDs. We

86 herein assess the extent to which the EAP was successful in terms of providing access

87 to COVID-19 convalescent plasma by presenting demographic, geographic, and 88 chronological characteristics of enrollment in the EAP alongside publicly available data of state-level trends in COVID-19.

90

91

92

93

94

95

96

97

98

99

100

101

102

103

104

105

106

\section{Methods}

As described previously [19-21], the EAP was a national registry for hospitalized patients with COVID-19. Collaborative support was provided by the US BARDA and FDA; funding to support the study infrastructure and study-related costs at participating sites was provided under contract from BARDA. Mayo Clinic served as the academic research organization coordinating the national registry. The Mayo Clinic Institutional Review Board (IRB), the central IRB for the registry, approved the protocol (IRB \#20-0033412, NCT\#: NCT04338360), all amendments, and provided regulatory oversight for all sites and investigators. The principal investigator (M.J.J.) was the regulatory sponsor. A Data and Safety Monitoring Board oversaw the safety analyses and advised the regulatory sponsor and the Mayo Clinic IRB on risk.

\section{Patients}

Patients were eligible for enrollment in the EAP if they were: aged 18 years or older, hospitalized with a laboratory confirmed diagnosis of or suspected/probable infection with severe acute respiratory syndrome coronavirus 2 (SARS-CoV-2), and either had or were judged by a healthcare provider to be at high risk of progression to severe or lifethreatening COVID-19. Severe COVID-19 was defined by one or more of the following: 
medRxiv preprint doi: https://doi.org/10.1101/2021.04.08.21255115; this version posted April 11, 2021. The copyright holder for this preprint (which was not certified by peer review) is the author/funder, who has granted medRxiv a license to display the preprint in perpetuity.

All rights reserved. No reuse allowed without permission.

dyspnea, respiratory frequency $\geq 30 / \mathrm{min}$, blood oxygen saturation $\leq 93 \%$, partial pressure of arterial oxygen to fraction of inspired oxygen ratio $<300$, lung infiltrates $>50 \%$ within 24 to 48 hours of hospital admission. Life-threatening COVID-19 was defined as one or more of the following: respiratory failure, septic shock, and multiple organ dysfunction or failure. To maximize access to COVID-19 convalescent plasma, no exclusion criteria were used, thereby, enabling access to vulnerable adult populations who may not be eligible for clinical trials, including pregnant women and prisoners.

\section{Enrollment}

All hospitals and acute care facilities in the US and its territories, and any physician licensed in the US, were allowed to register for participation provided they agreed to adhere to the online available treatment protocol [18], as well as US FDA and state regulations. All patient registration was facilitated through the central study website [22]. A single consent form, available in eight languages, was used by all participating sites. Informed consent was obtained from the patient or a legally authorized representative prior to enrollment, except for patients in whom an emergency consent was utilized. Criteria for emergency consent were consistent with the federal regulation governing emergency consent [23]. COVID-19 convalescent plasma transfusate and convalescent plasma donors details have been described elsewhere [19-21].

\section{Study data}

Demographic and clinical characteristics of enrolled patients were collected using the Research Electronic Data Capture system (REDCap, v.9.1.15 - v10.0.33 Vanderbilt University, Nashville, TN) [24, 25]. REDCap is US Health Insurance Portability and 
medRxiv preprint doi: https://doi.org/10.1101/2021.04.08.21255115; this version posted April 11, 2021. The copyright holder for this preprint (which was not certified by peer review) is the author/funder, who has granted medRxiv a license to display the preprint in perpetuity.

In order to contextualize whether the patients enrolled in the EAP were reflective of the

Accountability Act (HIPAA) compliant and the US FDA authorized its use in the EAP [20, 21]. The EAP was expeditiously established and implemented to provide access to a potential therapeutic for COVID-19 at a time when no satisfactory therapies for COVID19 were available. To maximize access in the context of stress on clinical staff at participating sites during the COVID-19 pandemic, the online case reporting forms were designed to optimize convenience. Race (American Indian or Alaska Native, Asian, Black or African American, Native Hawaiian or Other Pacific Islander, White) and ethnicity (Hispanic or Latino, Not Hispanic or Latino) were reported into categories by site personnel consistent with guidelines provided by the US Office of Management and Budget [26].

The database was updated as needed to fulfill the requirements of the EAP IRB and data collection requirements of BARDA. As the original goal of data collection was to determine safety, updates were needed to capture additional data as enrollment expanded and the study progressed. Enrollment into the EAP was stopped after the FDA issued an emergency use authorization (EUA) for COVID-19 convalescent plasma on August 23rd, 2020. Data clarification requests were sent to participating investigators as needed until the database was locked to further data changes on December 16th, 2020. The study protocol, case report forms with completion instructions, and informed consent form are publicly available on the study website [22], archived by the US Library of Congress.

\section{COVID-19 epidemiological data sources}

US population, race and ethnicity data of each state and US territories were retrieved 
medRxiv preprint doi: https://doi.org/10.1101/2021.04.08.21255115; this version posted April 11, 2021. The copyright holder for this preprint (which was not certified by peer review) is the author/funder, who has granted medRxiv a license to display the preprint in perpetuity.

All rights reserved. No reuse allowed without permission.

151 from the US Census Bureau [27], using the same race and ethnic categories that were 152 collected in the EAP. COVID-19-confirmed infection rates per day for each US state were 153 obtained from the New York Times database [28]. Hospital referral regions are regional 154 healthcare markets defined by where the majority of residents within that region have 155 their hospitalization stays. The 306 hospital referral regions in the US were retrieved from 156 the Dartmouth Atlas of Health Care. Metropolitan and less populated US region data were 157 obtained from US Census Bureau data [27] and the 2010 Office of Management and 158 Budget Standards that define metropolitan and micropolitan areas based on statistical 159 assessments [29]. Micropolitan areas were defined as areas with a population of at least 10,000 and less than 50,000 residents. The US regions of Northeast, Southeast, Midwest, Southwest, and West were delineated using commonly used regions [30]. Characteristics of US hospitals were retrieved from American Hospital Directory [31] and the Centers for Medicare and Medicaid [32]. The potential limitations of the data sources are described in the discussion.

\section{Statistical Considerations}

To provide a comprehensive report of the enrollment data on the EAP program descriptive statistics are presented for demographic and clinical variables of interest. To examine enrollment in the EAP over time, dot plots were used to show the number of enrollments,

169 for each US state individually and aggregated by region by day of the study. Additionally, 170 EAP enrollment was compared to the number of confirmed COVID-19 cases per state

171 over the duration of the study. During the window of EAP enrollment, a moving 7-day 172 average was calculated for daily enrollments and COVID-19 cases within each state that 173 enrolled more than 10 patients in total in the EAP. To compare and visualize relative 
medRxiv preprint doi: https://doi.org/10.1101/2021.04.08.21255115; this version posted April 11, 2021. The copyright holder for this preprint (which was not certified by peer review) is the author/funder, who has granted medRxiv a license to display the preprint in perpetuity.

All rights reserved. No reuse allowed without permission.

174 patterns, these averages were scaled between 0 (lowest cases/enrollments) and 1 (peak cases/enrollments) and overlaid on a geo-faceted graph. The geo-faceted graph contains one cell for each US state and is placed at approximately the same location on the graph

177 as the corresponding geographical location. Differences in geographic access to convalescent plasma through the EAP were assessed by examining enrollment across

179 micropolitan and metropolitan areas and the number of hospitals enrolling patients in each hospital referral region in the United States. All data were processed using $R$ version

$181 \quad 3.6 .2$.

182 Results

\section{Patient Characteristics}

From April 3rd to August 23rd, 2020, 105,717 hospitalized patients with severe or life-

185 threatening COVID-19 were enrolled in the EAP and $~ 95,000$ patients were transfused with COVID-19 convalescent plasma. The EAP halted enrollment forthwith after the US

187 FDA issued an emergency use authorization (EUA) for COVID-19 convalescent plasma, citing that the totality of scientific evidence indicated that convalescent plasma was safe $[20,21]$ and a potentially promising therapeutic treatment on August 23, 2020 [33]. This authorization enabled physicians to use COVID-19 convalescent plasma without requesting IND permission and obviated the need for access to convalescent plasma via 192 the EAP.

193 Enrolled patients' demographic characteristics including age, gender, race, ethnicity, and 194 other clinical variables at time of transfusion are shown in Table 1. A majority of patients 195 were older than 60 years of age (57.8\%), male (58.4\%), overweight or obese $(83.8 \%)$, 
medRxiv preprint doi: https://doi.org/10.1101/2021.04.08.21255115; this version posted April 11, 2021. The copyright holder for this preprint (which was not certified by peer review) is the author/funder, who has granted medRxiv a license to display the preprint in perpetuity.

All rights reserved. No reuse allowed without permission.

and had never smoked (69.7\%). There was substantial inclusion of minorities and underserved populations, including $46.4 \%$ of patients with a race other than White, and $37.2 \%$ of patients were of Hispanic ethnicity. Pre-existing conditions present among enrolled patients are displayed in Supplemental Table 1. Of those patients enrolled, $61.8 \%$ had severe or life-threatening COVID-19, $42.3 \%$ were in the ICU, and $18.9 \%$ received mechanical ventilation at time of transfusion. A small proportion of patients (3.9\%) had no form of hospital respiratory support prior to infusion. A large percentage of patients had severe risk factors of dyspnea (75.7\%), oxygen saturation $\leq 93 \%(75.0 \%)$, and acute respiratory failure (60.6\%). Patients were also prescribed steroids $(65.7 \%)$, azithromycin (49.0\%) and remdesivir (37.6\%) during their hospital stay. The median number of days between diagnosis of COVID-19 and the first transfusion was 4 days (interquartile range, 2 - 8 days), and nearly half of transfused patients $(45.0 \%)$ received convalescent plasma within 3 days of COVID-19 diagnosis, which often occurred during hospital admission.

Table 1. Characteristics of Patients with COVID-19 who enrolled in the US Expanded Access Program to convalescent plasma.

\begin{tabular}{lc}
\hline Baseline Data & $\begin{array}{c}\text { number/total } \\
\text { number (percent) }\end{array}$ \\
\hline Age at Enrollment (years) & \\
\hline 18 to 39 & $9,630 / 105,717(9.1)$ \\
\hline 40 to 59 & $34,968 / 105,717(33.1)$ \\
\hline 60 to 69 & $26,305 / 105,717(24.9)$ \\
\hline 70 to 79 & $21,585 / 105,717(20.4)$ \\
\hline 80 or older & $13,229 / 105,717(12.5)$ \\
\hline Gender & \\
\hline Female & $43,544 / 105,717(41.2)$ \\
\hline Male & $61,761 / 105,717(58.4)$ \\
\hline Intersex & $157 / 105,717(0.1)$ \\
\hline Transgender & $144 / 105,717(0.1)$ \\
\hline Prefer not to disclose & $111 / 105,717(0.1)$ \\
\hline
\end{tabular}


medRxiv preprint doi: https://doi.org/10.1101/2021.04.08.21255115; this version posted April 11, 2021. The copyright holder for this preprint (which was not certified by peer review) is the author/funder, who has granted medRxiv a license to display the preprint in perpetuity.

\begin{tabular}{|c|c|}
\hline \multicolumn{2}{|l|}{ Baseline Data } \\
\hline & $\begin{array}{c}\text { number/total } \\
\text { number (percent) }\end{array}$ \\
\hline \multicolumn{2}{|l|}{ Weight Status } \\
\hline Underweight & $1,528 / 104,046(1.5)$ \\
\hline Normal Weight & $15,313 / 104,046(14.7)$ \\
\hline Overweight & $28,524 / 104,046(27.4)$ \\
\hline Obese & $58,681 / 104,046(56.4)$ \\
\hline \multicolumn{2}{|l|}{ Race } \\
\hline American Indian and Alaska Native alone & $1,434 / 105,715(1.4)$ \\
\hline Asian alone & $3,432 / 105,715(3.2)$ \\
\hline Black alone & $19,225 / 105,715(18.2)$ \\
\hline Native Hawaiian and Other Pacific Islander alone & $605 / 105,715(0.6)$ \\
\hline White alone & $56,687 / 105,715(53.6)$ \\
\hline Other or Unknown & $23,849 / 105,715(22.6)$ \\
\hline Two or more races & $483 / 105,715(0.5)$ \\
\hline \multicolumn{2}{|l|}{ Ethnicity } \\
\hline Hispanic/Latino & $39,335 / 105,717(37.2)$ \\
\hline Not Hispanic/Latino & $66,382 / 105,717(62.8)$ \\
\hline \multicolumn{2}{|l|}{ Enrollment Month } \\
\hline April & $8,719 / 105,717(8.2)$ \\
\hline May & $15,873 / 105,717(15.0)$ \\
\hline June & $17,965 / 105,717(17.0)$ \\
\hline July & $39,321 / 105,717(37.2)$ \\
\hline August & $23,839 / 105,717(22.5)$ \\
\hline \multicolumn{2}{|l|}{ Smoking Status } \\
\hline Current smoker & $1,690 / 32,831(5.1)$ \\
\hline Past smoker & $8,250 / 32,831(25.1)$ \\
\hline Never smoked & $22,891 / 32,831(69.7)$ \\
\hline \multicolumn{2}{|l|}{ Transfusion Status } \\
\hline Transfused & $94,788 / 105,717(89.7)$ \\
\hline Plasma Not Ordered/Given & $8,177 / 105,717(7.7)$ \\
\hline Unreported & $2,752 / 105,717(2.6)$ \\
\hline Current severe or life-threatening COVID-19 & $65,336 / 105,717(61.8)$ \\
\hline \multicolumn{2}{|c|}{ Highest level of hospital respiratory support prior to transfusion } \\
\hline None & $3,619 / 93,776(3.9)$ \\
\hline Oxygen supplementation & $35,137 / 93,776(37.5)$ \\
\hline Non-Invasive Positive-Pressure Ventilation NIPPV & $36,454 / 93,776(38.9)$ \\
\hline Mechanical ventilation/intubation & $18,273 / 93,776(19.5)$ \\
\hline Extra Corporeal Membrane Oxygenation (ECMO) & $293 / 93,776(0.3)$ \\
\hline Intensive Care Unit (ICU) care prior to infusion & $39,929 / 94,383(42.3)$ \\
\hline Mechanical Ventilation prior to infusion & $17,864 / 94,328(18.9)$ \\
\hline \multicolumn{2}{|l|}{ Severe Risk Factors } \\
\hline Dyspnea & $49,486 / 65,336(75.7)$ \\
\hline Respiratory frequency $\geq 30 / \mathrm{min}$ & $25,520 / 65,336(39.1)$ \\
\hline Blood oxygen saturation $\leq 93 \%$ & $48,979 / 65,336(75.0)$ \\
\hline
\end{tabular}


medRxiv preprint doi: https://doi.org/10.1101/2021.04.08.21255115; this version posted April 11, 2021. The copyright holder for this preprint (which was not certified by peer review) is the author/funder, who has granted medRxiv a license to display the preprint in perpetuity.

\begin{tabular}{|c|c|}
\hline Baseline Data & \\
\hline & $\begin{array}{c}\text { number/total } \\
\text { number (percent) }\end{array}$ \\
\hline PaO2:FiO2 ratio $<300$ & $16,541 / 65,336(25.3)$ \\
\hline Lung infiltrates $>50 \%$ within 24 to 48 hours & $24,389 / 65,336(37.3)$ \\
\hline Respiratory failure & $39,617 / 65,336(60.6)$ \\
\hline Septic shock & $4,622 / 65,336(7.1)$ \\
\hline Multiple organ dysfunction or failure & $5,831 / 65,336(8.9)$ \\
\hline \multicolumn{2}{|l|}{ Medications during hospital stay } \\
\hline ARB & $2,942 / 43,805(6.7)$ \\
\hline Ace Inhibitor & $3,752 / 43,805(8.6)$ \\
\hline Azithromycin & $21,470 / 43,805(49.0)$ \\
\hline Remdesivir & $16,460 / 43,805(37.6)$ \\
\hline Steroids & $28,764 / 43,805(65.7)$ \\
\hline Chloroquine & $84 / 43,805(0.2)$ \\
\hline Hydroxychloroquine & $7,802 / 43,805(17.8)$ \\
\hline \multicolumn{2}{|l|}{ Census Region } \\
\hline Midwest & $14,896 / 105,717(14.1)$ \\
\hline Northeast & $11,557 / 105,717(10.9)$ \\
\hline South & $58,285 / 105,717(55.1)$ \\
\hline West & $20,748 / 105,717(19.6)$ \\
\hline Other & $231 / 105,717(0.2)$ \\
\hline \multicolumn{2}{|l|}{ Micro/Metropolitan } \\
\hline Metropolitan & $100,633 / 105,717(95.2)$ \\
\hline Micropolitan & $4,412 / 105,717(4.2)$ \\
\hline None & $672 / 105,717(0.6)$ \\
\hline Rural Referral Center & $16,566 / 104,534(15.8)$ \\
\hline Sole Community Hospital & $4,520 / 104,534(4.3)$ \\
\hline Part of a Health System & $89,234 / 104,534(85.4)$ \\
\hline Major Teaching Hospital (member of COTH) & $26,012 / 101,511(25.6)$ \\
\hline University Affiliated & $56,689 / 104,534(54.2)$ \\
\hline
\end{tabular}

\section{Geospatial Trends in Enrollment}

213 Patients were enrolled from each state in the US, the District of Columbia, and the US

214 territories of Puerto Rico, and the US Virgin Islands (Table 2). A large percentage of

215 patients were enrolled in the Southern region of the US (55.1\%) and most patients

216 enrolled in a hospital within a metropolitan area (95.2\%) that was part of a health system

217 (85.4\%) and/or was university affiliated (54.2\%). 
Table 2. Tabular summaries of patient enrollment in the US Expanded Access Program (EAP) to convalescent plasma and US COVID-19 cases during the EAP enrollment period, stratified by US state or territory in alphabetical order.

\begin{tabular}{|c|c|c|c|c|c|c|}
\hline \multirow[b]{2}{*}{ State } & \multicolumn{3}{|c|}{ EAP Summaries } & \multicolumn{3}{|c|}{ Population and COVID+ Ratios } \\
\hline & $\begin{array}{c}\text { Enrolling } \\
\text { Sites }\end{array}$ & $\begin{array}{l}\text { Enrolled } \\
\text { Patients } \\
\end{array}$ & $\begin{array}{c}\text { Transfused } \\
\text { Patients } \\
\end{array}$ & $\begin{array}{c}\text { COVID+ Cases / } \\
\text { Enrollment }\end{array}$ & $\begin{array}{l}\text { Enrollments / } \\
10,000 \text { people }\end{array}$ & $\begin{array}{c}\text { Enrollments / 1,000 } \\
\text { COVID+ Cases } \\
\end{array}$ \\
\hline Alabama & 35 & 2,408 & 2,016 & 51.9 & 4.9 & 19.3 \\
\hline Alaska & 3 & 59 & 58 & 100.5 & 0.8 & 9.9 \\
\hline Arizona & 41 & 3,961 & 3,680 & 50.6 & 5.4 & 19.8 \\
\hline Arkansas & 16 & 597 & 498 & 101.5 & 2.0 & 9.9 \\
\hline California & 236 & 11,874 & 10,076 & 59.2 & 3.0 & 16.9 \\
\hline Colorado & 27 & 646 & 628 & 84.3 & 1.1 & 11.9 \\
\hline Connecticut & 23 & 1,022 & 928 & 48.3 & 2.9 & 20.7 \\
\hline Delaware & 4 & 372 & 366 & 45.9 & 3.8 & 21.8 \\
\hline $\begin{array}{l}\text { District of } \\
\text { Columbia }\end{array}$ & 9 & 349 & 278 & 38.4 & 4.9 & 26.0 \\
\hline Florida & 158 & 12,553 & 11,206 & 49.0 & 5.8 & 20.4 \\
\hline Georgia & 74 & 5,424 & 4,921 & 46.0 & 5.1 & 21.7 \\
\hline Hawaii & 8 & 320 & 316 & 25.6 & 2.3 & 39.1 \\
\hline Idaho & 10 & 156 & 131 & 202.5 & 0.9 & 4.9 \\
\hline Illinois & 92 & 3,137 & 2,709 & 73.5 & 2.5 & 13.6 \\
\hline Indiana & 64 & 1,746 & 1,610 & 53.7 & 2.6 & 18.6 \\
\hline Iowa & 35 & 1,299 & 1,222 & 49.8 & 4.1 & 20.1 \\
\hline Kansas & 23 & 703 & 609 & 61.0 & 2.4 & 16.4 \\
\hline Kentucky & 40 & 884 & 836 & 56.8 & 2.0 & 17.6 \\
\hline Louisiana & 44 & 1,548 & 1,351 & 92.0 & 3.3 & 10.9 \\
\hline Maine & 9 & 62 & 58 & 67.5 & 0.5 & 14.8 \\
\hline Maryland & 42 & 1,812 & 1,592 & 58.9 & 3.0 & 17.0 \\
\hline Massachusetts & 37 & 907 & 790 & 133.2 & 1.3 & 7.5 \\
\hline Michigan & 61 & 1,071 & 875 & 97.0 & 1.1 & 10.3 \\
\hline Minnesota & 35 & 1,052 & 1,008 & 71.5 & 1.9 & 14.0 \\
\hline Mississippi & 19 & 1,380 & 1,313 & 59.3 & 4.6 & 16.9 \\
\hline Missouri & 41 & 1,347 & 1,262 & 62.9 & 2.2 & 15.9 \\
\hline Montana & 8 & 133 & 127 & 54.3 & 1.2 & 18.4 \\
\hline Nebraska & 18 & 509 & 471 & 66.9 & 2.6 & 15.0 \\
\hline Nevada & 19 & 1,303 & 1,128 & 52.2 & 4.2 & 19.2 \\
\hline $\begin{array}{l}\text { New } \\
\text { Hampshire }\end{array}$ & 8 & 127 & 92 & 54.0 & 0.9 & 18.5 \\
\hline New Jersey & 66 & 2,768 & 2,452 & 62.0 & 3.1 & 16.1 \\
\hline New Mexico & 14 & 433 & 415 & 57.7 & 2.1 & 17.3 \\
\hline New York & 110 & 4,492 & 4,146 & 79.1 & 2.3 & 12.6 \\
\hline $\begin{array}{l}\text { North } \\
\text { Carolina }\end{array}$ & 56 & 1,769 & 1,627 & 94.1 & 1.7 & 10.6 \\
\hline North Dakota & 7 & 226 & 216 & 51.7 & 3.0 & 19.4 \\
\hline Ohio & 77 & 2,184 & 2,007 & 55.2 & 1.9 & 18.1 \\
\hline Oklahoma & 27 & 1,415 & 1,324 & 41.0 & 3.6 & 24.4 \\
\hline Oregon & 17 & 320 & 290 & 81.2 & 0.8 & 12.3 \\
\hline
\end{tabular}


medRxiv preprint doi: https://doi.org/10.1101/2021.04.08.21255115; this version posted April 11, 2021. The copyright holder for this preprint (which was not certified by peer review) is the author/funder, who has granted medRxiv a license to display the preprint in perpetuity.

All rights reserved. No reuse allowed without permission.

\begin{tabular}{|c|c|c|c|c|c|c|}
\hline \multirow[b]{2}{*}{ State } & \multicolumn{3}{|c|}{ EAP Summaries } & \multicolumn{3}{|c|}{ Population and COVID+ Ratios } \\
\hline & $\begin{array}{c}\text { Enrolling } \\
\text { Sites }\end{array}$ & $\begin{array}{c}\text { Enrolled } \\
\text { Patients }\end{array}$ & $\begin{array}{c}\text { Transfused } \\
\text { Patients }\end{array}$ & $\begin{array}{c}\text { COVID+ Cases / } \\
\text { Enrollment }\end{array}$ & $\begin{array}{l}\text { Enrollments / } \\
10,000 \text { people }\end{array}$ & $\begin{array}{c}\text { Enrollments / 1,000 } \\
\text { COVID+ Cases }\end{array}$ \\
\hline Pennsylvania & 90 & 1,930 & 1,702 & 68.9 & 1.5 & 14.5 \\
\hline Puerto Rico & 31 & 222 & 184 & 148.3 & 0.7 & 6.7 \\
\hline Rhode Island & 9 & 248 & 242 & 86.2 & 2.3 & 11.6 \\
\hline $\begin{array}{l}\text { South } \\
\text { Carolina }\end{array}$ & 38 & 3,970 & 3,530 & 29.6 & 7.7 & 33.7 \\
\hline South Dakota & 6 & 427 & 409 & 31.3 & 4.8 & 31.9 \\
\hline Tennessee & 51 & 2,592 & 2,444 & 57.6 & 3.8 & 17.4 \\
\hline Texas & 221 & 19,363 & 17,507 & 32.8 & 6.7 & 30.4 \\
\hline Virgin Islands & 2 & 9 & 6 & 123.2 & & 8.1 \\
\hline Utah & 8 & 592 & 573 & 86.4 & 1.8 & 11.6 \\
\hline Vermont & 1 & 1 & 1 & $1,303.0$ & 0.0 & 0.8 \\
\hline Virginia & 51 & 1,747 & 1,480 & 68.2 & 2.0 & 14.7 \\
\hline Washington & 34 & 942 & 881 & 76.6 & 1.2 & 13.1 \\
\hline West Virginia & 11 & 102 & 88 & 98.6 & 0.6 & 10.1 \\
\hline Wisconsin & 62 & 1,195 & 1,100 & 66.3 & 2.1 & 15.1 \\
\hline Wyoming & 4 & 9 & 9 & 411.6 & 0.2 & 2.4 \\
\hline
\end{tabular}

221 Patients were enrolled by 12,879 healthcare providers from 2,722 hospitals and acute

222 care facilities across the US, Figure 1. COVID-19 convalescent plasma was provided by

223317 blood banks. The median number of participants per site was 22 (range, 1 to 1,175 ).

224 While 2,722 sites were registered, 490 (18.0\%) enrolled no patients, 732 (26.9\%) enrolled 225 between 1 and 10 patients, and 1,500 (55.1\%) enrolled more than 10 patients. Registered 226 sites encompassed nearly all hospital referral regions in the US, Figure 2. Sites

227 participation occurred both in metropolitan and non-metropolitan areas and from different 228 hospital types ranging from community hospitals to major teaching hospitals, Table 1 and 229 Supplemental Table 2. 


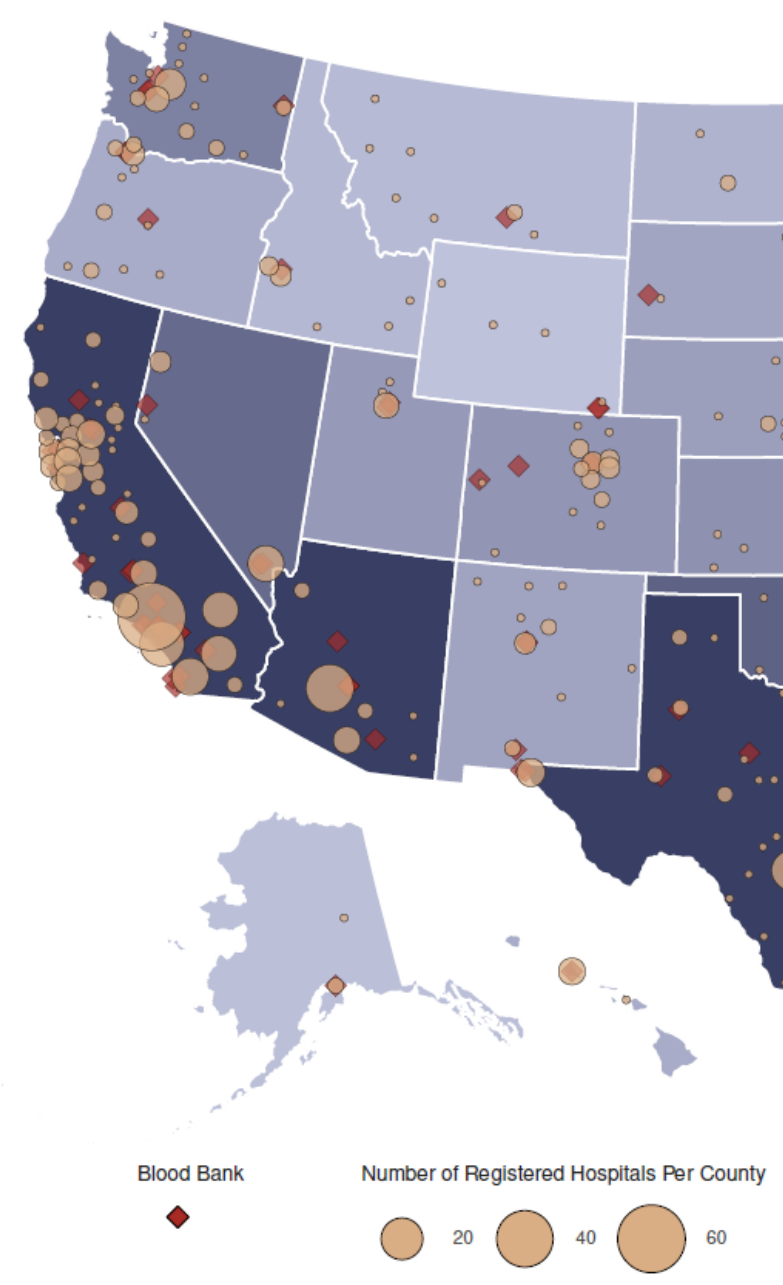

Figure 1. Participation in the US Expanded Access Program (EAP) to convalescent plasma. Choropleth map displaying the number of cumulatively enrolled patients in the EAP within each state of the US and participating territories, with lower enrollment values displayed in a lighter shade and higher enrollment values displayed in a darker shade of blue. Registered acute care facilities are represented as filled yellow circles, with larger circles indicating greater number of registered facilities within the county. Blood collection centers are represented as filled red diamonds. All sites with registered patients were included. The choropleth map does not display Guam or the Northern Mariana Islands. 


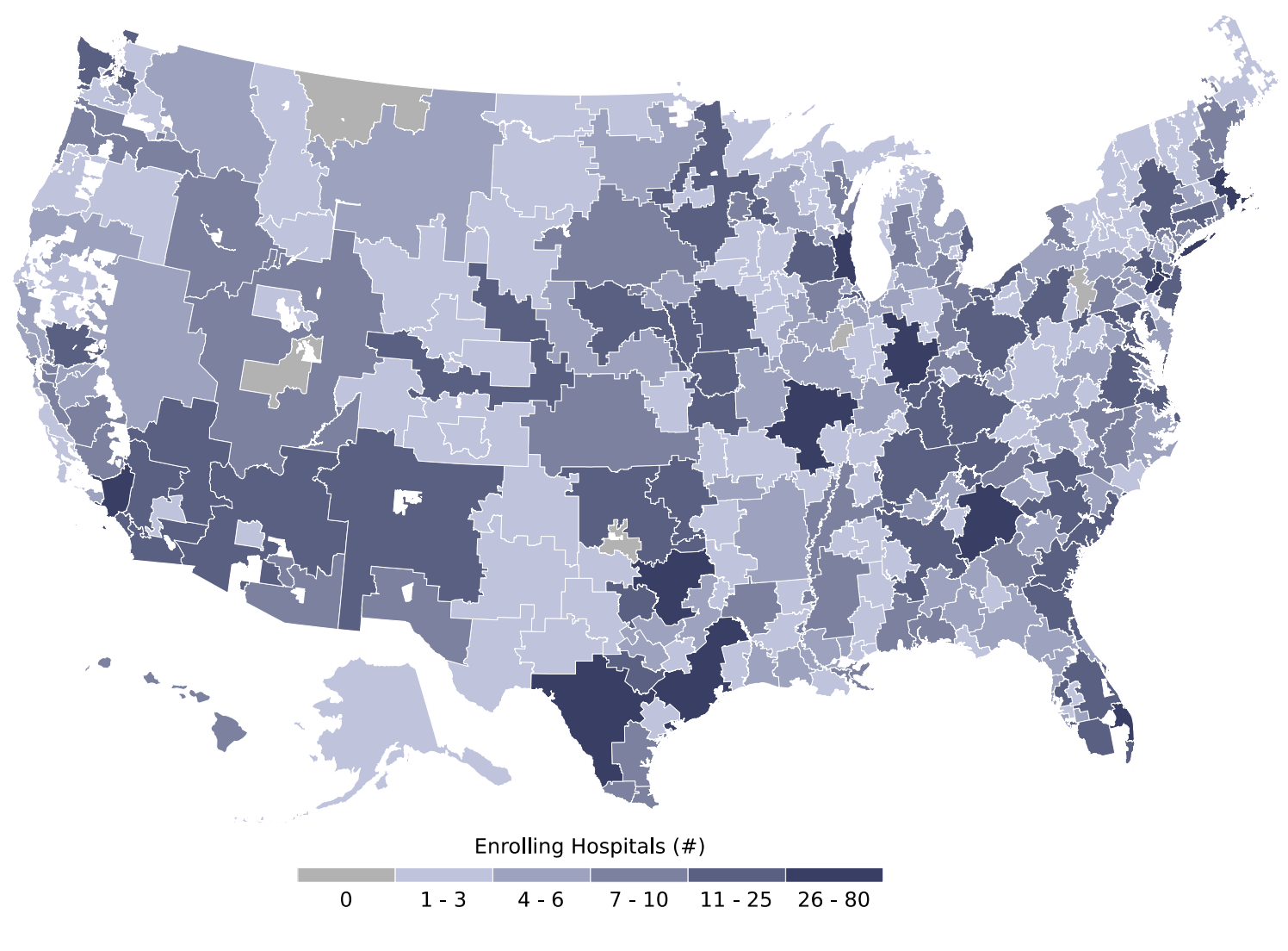
(EAP) to convalescent plasma stratified by US hospital referral region. Choropleth map displaying the number of participating acute care facilities which enrolled patients in the EAP within each hospital referral region - a geographical regions which represent a catchment region of patients who get health care at similar facilities. Lower numbers of participating acute care facilities are displayed in a lighter hue of blue and higher numbers of participating acute care facilities are displayed in a darker hue of blue. Hospital referral regions with zero participating acute care facilities are displayed in grey. Hospital referral regions are not defined in US territories; thus, the choropleth map does not display data from Puerto Rico, the US Virgin Islands, Guam or the Northern Mariana Islands.

Recognizing the disproportionate effects of the COVID-19 pandemic on minority groups is displayed in Figure 3, relative to 100,000 people from US census. 

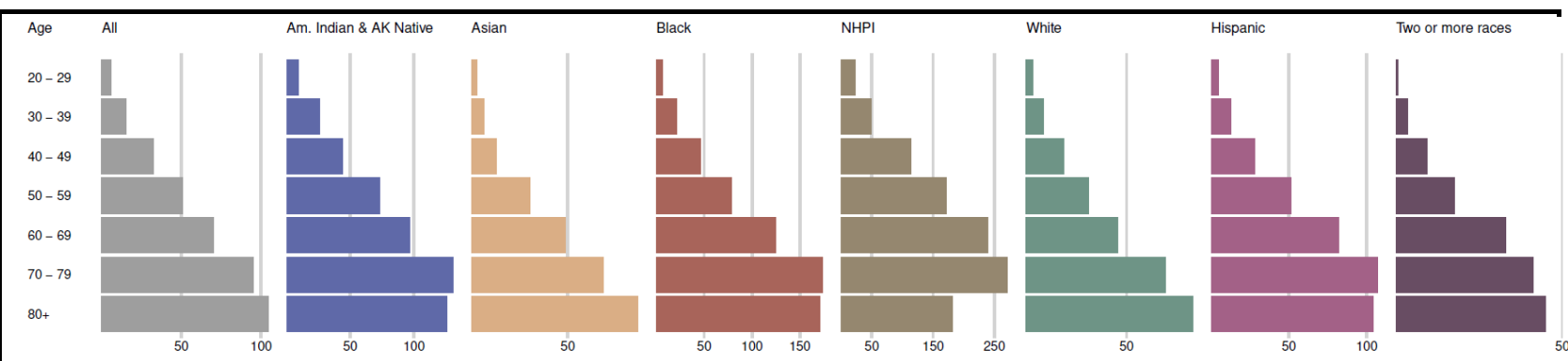

Figure 3. Patient enrollment in the US Expanded Access Program (EAP) stratified by race and ethnic group, relative to 100,000 people from US census per age, race and ethnicity. The length of each colored bar is proportional to the number of patients enrolled in the US EAP within the identified age group (years) and race or ethnicity category. The patient enrollment values are presented relative to analogous categorical data retrieved from the US Census Bureau.

\section{Temporal Trends in Enrollment}

Enrollment in the EAP for convalescent plasma per US state on each day of the EAP is

displayed in Figure 4. The individual state and regional aggregates show clear trends of when COVID-19 was surging during EAP enrollment. Figure 5 presents enrollment over time together with the number of active COVID-19 cases per US state. Chronologically, increases in enrollment in the EAP closely followed the individual state infection rate. Enrollment in the EAP per 1,000 confirmed COVID-19 cases varied from 0.8 (Vermont)

269 to 39.1 (Hawaii) patients across US states. The proportion that each US region contributed to the total enrollment into the EAP varied throughout the program and Figure

2716 displays proportional enrollment into the EAP across time by US geographical region,

272 COVID-19 disease severity, and mechanical ventilation status prior to COVID-19 273 convalescent plasma transfusion. 


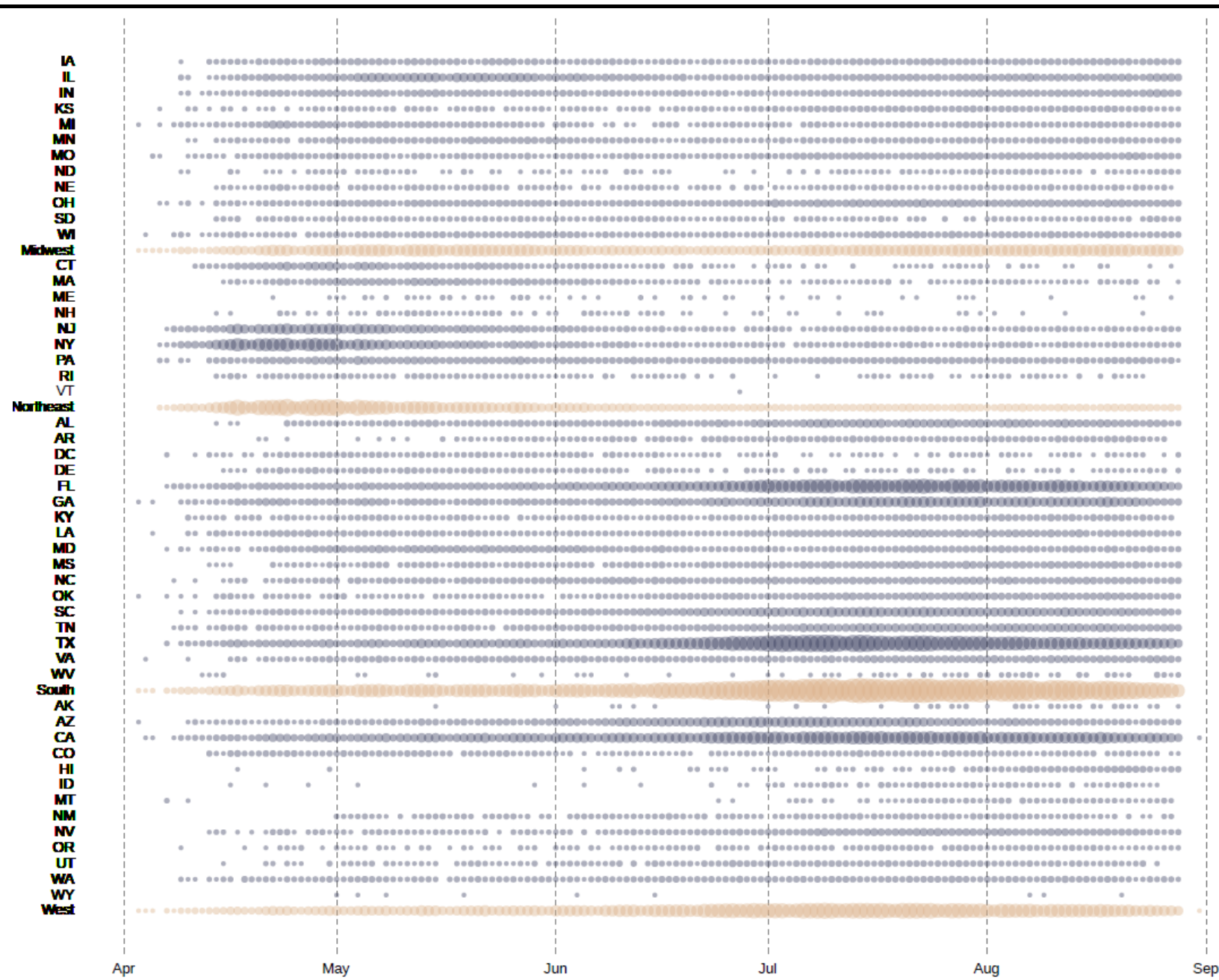

Figure 4. Daily patient enrollment in the US Expanded Access Program (EAP). Each circle represents one day in which at least one patient was enrolled, within the indicated US state or region. Blue circles represent daily US state enrollments and yellow circles represent daily US region enrollments. Larger circles represent a greater number of daily are not represented with a symbol. States are ordered alphabetically by US region, and an aggregate for each region is also represented. 


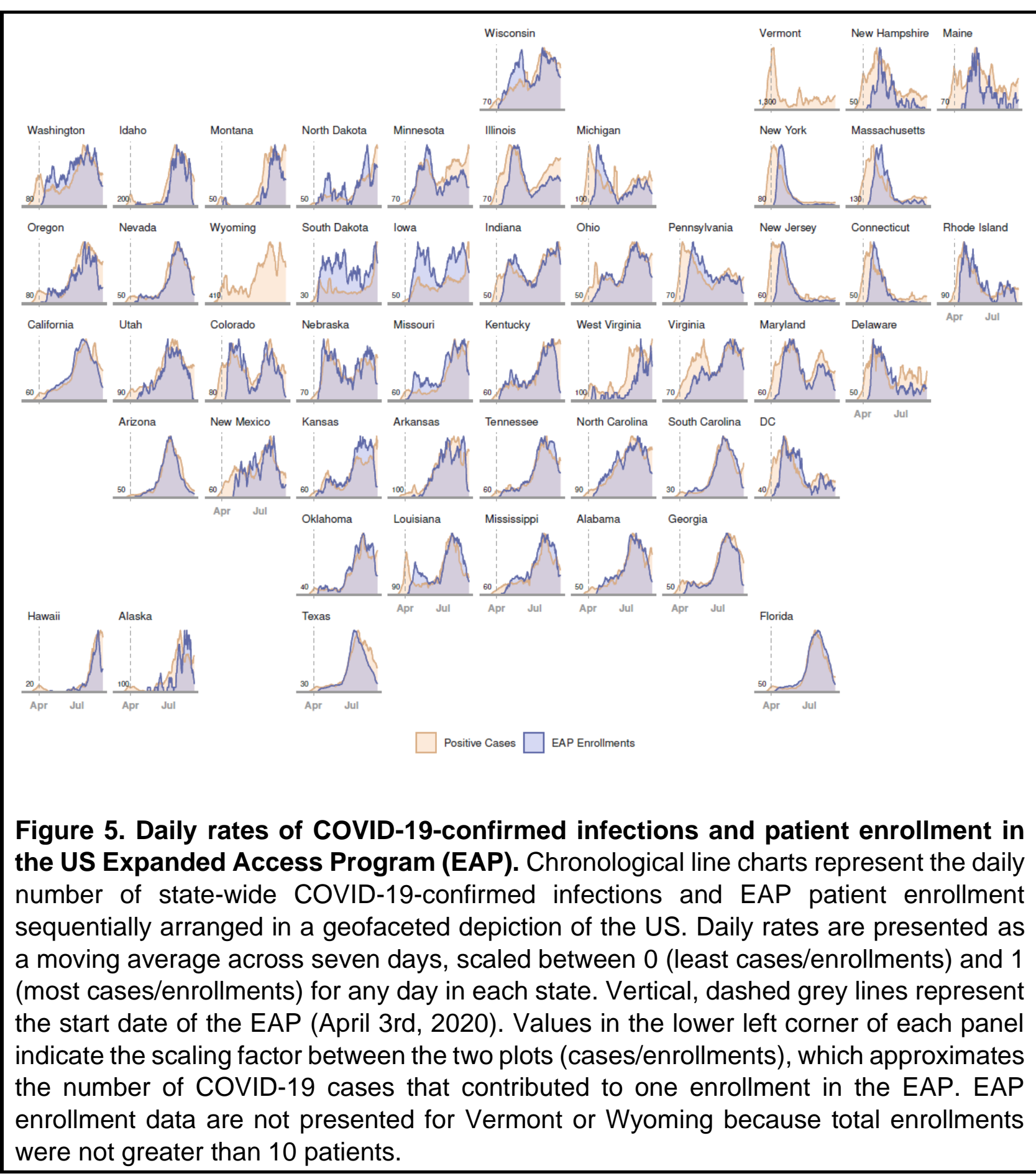



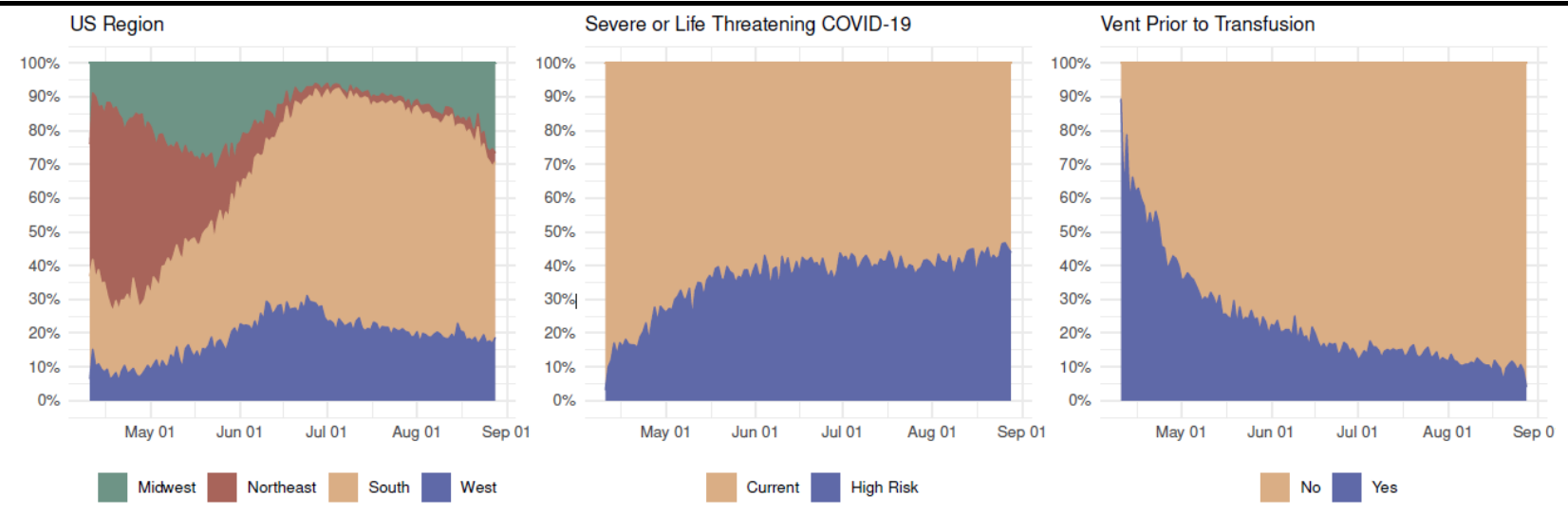

Figure 6. Daily patient enrollment in the US Expanded Access Program (EAP) relative to each US geographical region. Stacked area chart displaying daily rates of patient enrollment in the EAP as a proportion of the sum total daily enrollment within each of four US geographical regions, two categories of COVID-19 disease severity (severe or life-threatening), and dichotomous representation of mechanical ventilation status prior to COVID-19 convalescent plasma transfusion. Only patients that received a COVID-19 convalescent plasma transfusion are included in the rightmost panel dichotomized by mechanical ventilation status.

\section{Discussion}

The US EAP successfully provided access to COVID-19 convalescent plasma to over 105,000 patients, of which nearly 95,000 patients were transfused with convalescent plasma over the course of five months. Access to convalescent plasma closely kept pace with increases in confirmed US COVID-19 infections per state over time and there was substantial inclusion of vulnerable racial and ethnic minority populations. Geographically, enrollment in the EAP occurred in all US States, the District of Columbia, and the US territories of Puerto Rico, and the U.S. Virgin Islands. Patients were enrolled from all but

314 five of US national hospital referral regions, and substantial enrollment occurred in both metropolitan and non-metropolitan areas. 
medRxiv preprint doi: https://doi.org/10.1101/2021.04.08.21255115; this version posted April 11, 2021. The copyright holder for this preprint (which was not certified by peer review) is the author/funder, who has granted medRxiv a license to display the preprint in perpetuity.

All rights reserved. No reuse allowed without permission.

\section{Demographic characteristics of patients enrolled in the EAP}

317 Demographic characteristics of the complete enrolled EAP cohort showed substantial

318 enrollment among patients over the age of 60 (57.8\%), male patients (58.4\%), patients of

319 African American or Black race (18.2\%), and patients of Hispanic or Latino ethnicity

320 (37.2\%). African American or Black race and Hispanic or Latino ethnicity make up 13.4\%

321 and $18.5 \%$ of the US population, respectively [27]. Previous studies have found that older

$322[34,35]$, male [35], African American or Black race [34, 36, 37], and Hispanic or Latino

[37] individuals are at higher risk of hospitalization for severe or life-threatening COVID-

324 19. The presented enrollment results from the EAP highlight that this program was able

325 to provide access to COVID-19 convalescent plasma to demographic groups that have suffered the largest disease burden from the US COVID-19 epidemic.

327 Chronological and Geographical characteristics

Peak enrollment in the EAP per day closely tracked the number of cases reported by state as the COVID-19 epidemic developed. Enrollment during April and May, 2020 was high in Northeastern states, whereas in July and August enrollment peaked in the Southeast and Southwest regions of mainland US, in line with the development of 332 'hotspots' in these regions over time [38]. An increase in enrollment in Midwestern states was observed during August 2020, and this trend was also closely associated with an increase in confirmed COVID-19 cases in that region. Although there was widespread participation across US states and territories, there were less than 10 patients enrolled in both Vermont $(n=1)$ and Wyoming $(n=9)$, representing a small fraction of the total COVID-19 cases in those states. Given that there were no registered clinical trials

338 involving COVID-19 convalescent plasma in these two states during the time of the EAP, 
medRxiv preprint doi: https://doi.org/10.1101/2021.04.08.21255115; this version posted April 11, 2021. The copyright holder for this preprint (which was not certified by peer review) is the author/funder, who has granted medRxiv a license to display the preprint in perpetuity.

All rights reserved. No reuse allowed without permission.

339 there may have been regulatory or administrative barriers to participation in trials involving experimental therapeutics for COVID-19.

341 Implications for future pandemics

342 The success of the EAP in providing rapid access to convalescent plasma in metropolitan

343 and regional areas of the US that might not otherwise have had access to therapy

344 provides a framework for future efforts when broad access to a treatment is needed in

345 response to an infectious disease outbreak. In this regard it is noteworthy that given that

346 clinical trials were limited to only a few institutions, that most patients treated with plasma

347 would have had no access without the EAP or single-patient elNDs. The high use of 348 convalescent plasma within the EAP indicates a high level of acceptance for this therapy

349 by patients and frontline physicians despite the absence of high-quality data for its clinical

350 efficacy. The EAP design was particularly effective in providing access to a potentially

351 effective treatment in minority demographic groups and rural areas that are often

352 underrepresented in US randomized controlled trials [39, 40].

\section{Methodological considerations}

354 The US EAP for COVID-19 convalescent plasma aimed to provide access to a treatment 355 possibly providing benefit, while randomized clinical trials were in various stages of 356 development and enrollment. This enrollment report focused on the primary aim of the 357 EAP of providing access to COVID-19 convalescent plasma; whereas, analyses on 358 potential efficacy from EAP data have been presented elsewhere [19, 41]. 
medRxiv preprint doi: https://doi.org/10.1101/2021.04.08.21255115; this version posted April 11, 2021. The copyright holder for this preprint (which was not certified by peer review) is the author/funder, who has granted medRxiv a license to display the preprint in perpetuity.

All rights reserved. No reuse allowed without permission. that were severely affected by COVID-19.

\section{Conclusions}

Numerous challenges were encountered during the development and implementation of this national registry. Given the constraints on health care resources during the COVID-19 pandemic [42], this national registry used a modern design with creative solutions to overcome the epidemiological and contextual challenges of the pandemic [43]. These creative solutions included a central academic IRB for oversight, streamlined registration for sites and physicians, simple online data collection forms, robust support center accessible via email or telephone, limited patient exclusion criteria, limited restrictions on concomitant therapies, and no initiation or monitoring site visits. Several important limitations resulted from this design, however, including adjustments in required data collection elements which were inversely related to the number of cases of COVID-19 in the US, unavailable data due to abridged data collection forms, and missing data due to the nature of a national registry. Additionally, the EAP was designed to provide access to convalescent plasma at hospitals and acute care facilities that were not already part of a clinical trial or did not have the infrastructure to support complex clinical trials. This registry also did not require training of the local investigators or study team members. The design of this national registry provided widespread access to convalescent plasma and easy to complete data collection forms during a worldwide pandemic. This pragmatic approach did not ensure the highest quality of data nor completeness of data.

The EAP provided rapid and broad access to convalescent plasma throughout the US and some US territories and was effective at providing therapy for demographic groups convalescent plasma in response to sudden and exponential changes in SARS-CoV-2 
medRxiv preprint doi: https://doi.org/10.1101/2021.04.08.21255115; this version posted April 11, 2021. The copyright holder for this preprint (which was not certified by peer review) is the author/funder, who has granted medRxiv a license to display the preprint in perpetuity.

All rights reserved. No reuse allowed without permission.

383 infection rates. Data gathered from the EAP established the COVID-19 convalescent plasma was generally safe $[20,21]$ and provided key efficacy data that were an important component of the scientific evidence considered by the US FDA in the decision to issue an EUA [19] for convalescent plasma in the treatment of hospitalized adults with COVID19. Hence, this program established that it is possible to obtain relevant and actionable safety and efficacy data during pandemic conditions. The efficient study design of the EAP may serve as an example for future efforts when broad access to a treatment is needed in response to a rapidly developing infectious disease providing access in areas typically underrepresented in clinical studies and thereby allowing capture of demographic groups that are often poorly represented in clinical trials.

\section{Article Information}

Disclaimer: The views and opinions expressed in this manuscript are those of the authors and do not reflect the official policy or position of the US Department of Health and Human Services and its agencies including the Biomedical Research and

397 Development Authority and the Food and Drug Administration, as well as any agency of the U.S. government. Assumptions made within and interpretations from the analysis are not reflective of the position of any US government entity.

Author Contributions: Drs. Joyner and Carter had full access to all the data in the study and take responsibility for the integrity of the data and the accuracy of the data analysis.

Conflict of Interest Disclosures: United Health Group, Millennium Pharmaceuticals, and Octapharma USA Inc., supported this project. No other disclosures were reported. 
medRxiv preprint doi: https://doi.org/10.1101/2021.04.08.21255115; this version posted April 11, 2021. The copyright holder for this preprint (which was not certified by peer review) is the author/funder, who has granted medRxiv a license to display the preprint in perpetuity.

All rights reserved. No reuse allowed without permission.

404 Funding/Support: This project has been funded in part with Federal funds from the Department of Health and Human Services; Office of the Assistant Secretary for Preparedness and Response; Biomedical Advanced Research and Development Authority under Contract No. 75A50120C00096. Additionally, this study was supported in part by National Center for Advancing Translational Sciences (NCATS) grant UL1TR002377, National Heart, Lung, and Blood Institute (NHLBI) grant 5R35HL139854 (to MJJ) and grant 1F32HL154320 (to JWS), Natural Sciences and Engineering Research Council of Canada (NSERC) PDF-532926-2019 (to SAK), National Institute of Diabetes and Digestive and Kidney Diseases (NIDDK) 5T32DK07352 (to CCW), National Institute of Allergy and Infectious Disease (NIAID) grants R21 Al145356, R21 Al152318 and R21

414 Al154927 (to DF), R01 Al152078 9 (to AC), National Heart Lung and Blood Institute RO1 415 HL059842 (to AC), National Institute on Aging (NIA) U54AG044170 (to SEB), Schwab 416 Charitable Fund (Eric E Schmidt, Wendy Schmidt donors), United Health Group, National 417 Basketball Association (NBA), Millennium Pharmaceuticals, Octapharma USA, Inc, and 418 the Mayo Clinic.

Data Access Statement: Individual participant data underlying the results reported in 420 this publication, along with a data dictionary, will be made available to approved 421 investigators for secondary analyses following the completion of the objectives of the 422 United States Expanded Access Program to COVID-19 convalescent plasma. Limited 423 and de-identified data sets will be deposited into a research data repository and may be 424 shared with investigators under controlled access procedures as approved by the Mayo 425 Clinic Institutional Review Board. A scientific committee will review requests for the 426 conduct of protocols approved or determined to be exempt by an Institutional Review 
medRxiv preprint doi: https://doi.org/10.1101/2021.04.08.21255115; this version posted April 11, 2021. The copyright holder for this preprint (which was not certified by peer review) is the author/funder, who has granted medRxiv a license to display the preprint in perpetuity. All rights reserved. No reuse allowed without permission.

427 Board. Requestors will be required to sign a data use agreement. Data sharing must be 428 compliant with all applicable Mayo Clinic policies. 


\section{References}

430 1. The L. COVID-19 in the USA: a question of time. Lancet (London, England).

431 2020;395(10232):1229. Epub 2020/04/20. doi: 10.1016/s0140-6736(20)30863-1.

432 PubMed PMID: 32305080; PubMed Central PMCID: PMCPMC7162627.

433 2. Oran DP, Topol EJ. Prevalence of Asymptomatic SARS-CoV-2 Infection : A

434 Narrative Review. Ann Intern Med. 2020;173(5):362-7. Epub 2020/06/04. doi: 435 10.7326/M20-3012. PubMed PMID: 32491919; PubMed Central PMCID: 436 PMCPMC7281624.

437 3. Richardson S, Hirsch JS, Narasimhan M, Crawford JM, McGinn T, Davidson KW, 438 et al. Presenting Characteristics, Comorbidities, and Outcomes Among 5700 Patients 439 Hospitalized With COVID-19 in the New York City Area. JAMA. 2020. Epub 2020/04/23. 440 doi: 10.1001/jama.2020.6775. PubMed PMID: 32320003; PubMed Central PMCID: 441 PMCPMC7177629.

442 4. Gupta S, Hayek SS, Wang W, Chan L, Mathews KS, Melamed ML, et al. Factors 443 Associated With Death in Critically III Patients With Coronavirus Disease 2019 in the US. 444 JAMA Intern Med. 2020. Epub 2020/07/16. doi: 10.1001/jamainternmed.2020.3596. 445 PubMed PMID: 32667668; PubMed Central PMCID: PMCPMC7364338.

446 5. Fan E, Beitler JR, Brochard L, Calfee CS, Ferguson ND, Slutsky AS, et al. COVID447 19-associated acute respiratory distress syndrome: is a different approach to 448 management warranted? Lancet Respir Med. 2020;8(8):816-21. Epub 2020/07/10. doi: 
10.1016/S2213-2600(20)30304-0. PubMed PMID: 32645311; PubMed Central PMCID: PMCPMC7338016.

6. Klassen SA, Senefeld JW, Johnson PW, Carter RE, Wiggins CC, Shoham S, et al. Evidence favoring the efficacy of convalescent plasma for COVID-19 therapy. medRxiv. 2020:2020.07.29.20162917. Epub 2020/11/04. doi: 10.1101/2020.07.29.20162917. PubMed PMID: 33140056; PubMed Central PMCID: PMCPMC7605561.

7. Ripoll Sanz J, van Helmond N, Senefeld JW, Wiggins CC, Klassen SA, Baker SE, et al. Convalescent Plasma for Infectious Diseases: Historical Framework and Use in COVID-19. Clinical Microbiology Newsletter. 2021; ahead of print.

8. Luke TC, Casadevall A, Watowich SJ, Hoffman SL, Beigel JH, Burgess TH. Hark back: passive immunotherapy for influenza and other serious infections. Crit Care Med. 2010;38(4 Suppl):e66-73. Epub 2010/02/16. doi: 10.1097/CCM.0b013e3181d44c1e. PubMed PMID: 20154602.

9. Casadevall A, Scharff MD. Serum therapy revisited: animal models of infection and development of passive antibody therapy. Antimicrob Agents Chemother. 1994;38(8):1695-702. Epub 1994/08/01. doi: 10.1128/aac.38.8.1695. PubMed PMID: 7985997; PubMed Central PMCID: PMCPMC284624.

10. Casadevall A, Scharff MD. Return to the past: the case for antibody-based therapies in infectious diseases. Clin Infect Dis. 1995;21(1):150-61. Epub 1995/07/01. 
468

469

470

471

472

473

474

475

476

477

478

479

480

481

482

483

484

485

doi: 10.1093/clinids/21.1.150. PubMed PMID: 7578724; PubMed Central PMCID: PMCPMC7197598.

11. Cheng Y, Wong R, Soo YO, Wong WS, Lee CK, Ng MH, et al. Use of convalescent plasma therapy in SARS patients in Hong Kong. Eur J Clin Microbiol Infect Dis. 2005;24(1):44-6. Epub 2004/12/24. doi: 10.1007/s10096-004-1271-9. PubMed PMID: 15616839; PubMed Central PMCID: PMCPMC7088355.

12. Shen C, Wang Z, Zhao F, Yang Y, Li J, Yuan J, et al. Treatment of 5 Critically III Patients With COVID-19 With Convalescent Plasma. Jama. 2020;323(16):1582-9. doi: 10.1001/jama.2020.4783.

13. Li L, Zhang W, Hu Y, Tong X, Zheng S, Yang J, et al. Effect of Convalescent Plasma Therapy on Time to Clinical Improvement in Patients With Severe and Lifethreatening COVID-19: A Randomized Clinical Trial. Jama. 2020;324(5):460-70. Epub 2020/06/04. doi: 10.1001/jama.2020.10044. PubMed PMID: 32492084; PubMed Central PMCID: PMCPMC7270883 COVID-19 testing. Dr Wu reports consulting for Verax Medical and Grifols, receiving royalties from UptoDate and AABB, and being a volunteer visiting professor and receiving travel support for giving medical education from the Chinese Institute of Blood Transfusion. No other disclosures were reported.

14. Salazar E, Perez KK, Ashraf M, Chen J, Castillo B, Christensen PA, et al. Treatment of Coronavirus Disease 2019 (COVID-19) Patients with Convalescent Plasma. 
Am J Pathol. 2020;190(8):1680-90. Epub 2020/05/31. doi: 10.1016/j.ajpath.2020.05.014. PubMed PMID: 32473109; PubMed Central PMCID: PMCPMC7251400.

15. Liu STH, Lin HM, Baine I, Wajnberg A, Gumprecht JP, Rahman F, et al. Convalescent plasma treatment of severe COVID-19: a propensity score-matched control study. Nat Med. 2020;26(11):1708-13. Epub 2020/09/17. doi: 10.1038/s41591-020-10889. PubMed PMID: 32934372.

16. Egede LE, Walker RJ. Structural Racism, Social Risk Factors, and Covid-19 - A Dangerous Convergence for Black Americans. N Engl J Med. 2020;383(12):e77. Epub 2020/07/25. doi: 10.1056/NEJMp2023616. PubMed PMID: 32706952; PubMed Central PMCID: PMCPMC7747672.

17. Evans MK. Covid's Color Line - Infectious Disease, Inequity, and Racial Justice. N Engl J Med. 2020;383(5):408-10. Epub 2020/07/30. doi: 10.1056/NEJMp2019445. PubMed PMID: 32726526.

18. Joyner MJ. Expanded Access to Convalescent Plasma for the Treatment of Patients with COVID-19. Rochester, MN, US.2020 [updated 08/03/2020; cited 2020 10/23/2020]. 1.0:[Available from: https://www.uscovidplasma.org/physicians-protocol.

19. Joyner MJ, Carter RE, Senefeld JW, Klassen SA, Mills JR, Johnson PW, et al. Convalescent Plasma Antibody Levels and the Risk of Death from Covid-19. New England Journal of Medicine. 2021. doi: 10.1056/NEJMoa2031893. 
medRxiv preprint doi: https://doi.org/10.1101/2021.04.08.21255115; this version posted April 11, 2021. The copyright holder for this preprint (which was not certified by peer review) is the author/funder, who has granted medRxiv a license to display the preprint in perpetuity. All rights reserved. No reuse allowed without permission.

522 523 electronic data capture (REDCap)--a metadata-driven methodology and workflow

20. Joyner MJ, Bruno KA, Klassen SA, Kunze KL, Johnson PW, Lesser ER, et al. Safety Update: COVID-19 Convalescent Plasma in 20,000 Hospitalized Patients. Mayo Clin Proc. 2020;95(9):1888-97. Epub 2020/08/31. doi: 10.1016/j.mayocp.2020.06.028. PubMed PMID: 32861333; PubMed Central PMCID: PMCPMC7368917.

21. Joyner MJ, Wright RS, Fairweather D, Senefeld JW, Bruno KA, Klassen SA, et al. Early safety indicators of COVID-19 convalescent plasma in 5000 patients. J Clin Invest. 2020;130(9):4791-7. Epub 2020/06/12. doi: 10.1172/JCl140200. PubMed PMID: 32525844; PubMed Central PMCID: PMCPMC7456238.

22. Mayo Clinic. USCovidPlasma. Rochester, MN, US.2020 [cited 2020 10/23/2020]. Available from: https://www.uscovidplasma.org/.

23. US Food and Drug Administration. Code of Federal Regulations Title 21 - Part 50 Section 50.23. 2019.

24. Harris PA, Taylor R, Minor BL, Elliott V, Fernandez M, O'Neal L, et al. The REDCap consortium: Building an international community of software platform partners. J Biomed Inform. 2019;95:103208. Epub 2019/05/13. doi: 10.1016/j.jbi.2019.103208. PubMed PMID: 31078660; PubMed Central PMCID: PMCPMC7254481.

22 25. Harris PA, Taylor R, Thielke R, Payne J, Gonzalez N, Conde JG. Research 24 process for providing translational research informatics support. J Biomed Inform. 
medRxiv preprint doi: https://doi.org/10.1101/2021.04.08.21255115; this version posted April 11, 2021. The copyright holder for this preprint (which was not certified by peer review) is the author/funder, who has granted medRxiv a license to display the preprint in perpetuity. All rights reserved. No reuse allowed without permission.

525 2009;42(2):377-81. Epub 2008/10/22. doi: 10.1016/j.jbi.2008.08.010. PubMed PMID:

526 18929686; PubMed Central PMCID: PMCPMC2700030.

527 26. OFFICE OF MANAGEMENT AND BUDGET. Revisions to the Standards for the

528 Classification of Federal Data on Race and Ethnicity. Federal Register; 1997. p. 58782.

529 27. U.S. Census Bureau. Population Estimates 2018. Available from:

530 https://www2.census.gov/programs-surveys/popest/datasets/2010-2018/counties/asrh/.

531 28. The New York Times. Coronavirus US Cases New York City: The New York Times

532 Company; $2020 . \quad$ Available from:

533 https://www.nytimes.com/interactive/2020/us/coronavirus-us-cases.html.

534 29. Office of Management and Budget. Standards for Delineating Metropolitan 535 and Micropolitan Statistical Areas; Notice Federal Register; 2010. p. 37249-52.

536 30. O'Connor SP. United States Regions Washington DC: National Geographic 537 Society 2012 [01/14/2021]. Available from:

538 https://www.nationalgeographic.org/maps/united-states-regions/.

539 31. American Hospital Directory. Hospital Profiles 2020 [01/14/2021]. Available from: 540 https://www.ahd.com/search.php. 
medRxiv preprint doi: https://doi.org/10.1101/2021.04.08.21255115; this version posted April 11, 2021. The copyright holder for this preprint (which was not certified by peer review) is the author/funder, who has granted medRxiv a license to display the preprint in perpetuity.

All rights reserved. No reuse allowed without permission.

541 32. CMS. Provider of Services Baltimore: Centers for Medicare \& Medicaid Services;

542 2020. Available from: https://www.cms.gov/Research-Statistics-Data-and-

543 Systems/Downloadable-Public-Use-Files/Provider-of-Services.

544 33. Hilton DM. Letter of authorization Silver Spring: US Food \& Drug Administration; $5452020[01 / 14 / 2021]$

546 34. Gold JAW, Wong KK, Szablewski CM, Patel PR, Rossow J, da Silva J, et al.

547 Characteristics and Clinical Outcomes of Adult Patients Hospitalized with COVID-19 -

548 Georgia, March 2020. MMWR Morb Mortal Wkly Rep. 2020;69(18):545-50. Epub

549 2020/05/08. doi: 10.15585/mmwr.mm6918e1. PubMed PMID: 32379729; PubMed

550 Central PMCID: PMCPMC7737948 Journal Editors form for disclosure of potential

551 conflicts of interest. James M. Blum reports personal fees from Clew Medical, outside the

552 submitted work. No other potential conflicts of interest were disclosed.

553 35. Myers LC, Parodi SM, Escobar GJ, Liu VX. Characteristics of Hospitalized Adults

554 With COVID-19 in an Integrated Health Care System in California. Jama.

555 2020;323(21):2195-8. Epub 2020/04/25. doi: 10.1001/jama.2020.7202. PubMed PMID:

556 32329797; PubMed Central PMCID: PMCPMC7182961 National Institutes of Health

557 (R35GM128672) during the conduct of the study. No other disclosures were reported.

558 36. Price-Haywood EG, Burton J, Fort D, Seoane L. Hospitalization and Mortality 559 among Black Patients and White Patients with Covid-19. The New England journal of 
medRxiv preprint doi: https://doi.org/10.1101/2021.04.08.21255115; this version posted April 11, 2021. The copyright holder for this preprint (which was not certified by peer review) is the author/funder, who has granted medRxiv a license to display the preprint in perpetuity. All rights reserved. No reuse allowed without permission.

560

561

562

563

564

565

566

567

568

569

570

571 572 reported.

573 38. Oster AM, Kang GJ, Cha AE, Beresovsky V, Rose CE, Rainisch G, et al. Trends

574 in Number and Distribution of COVID-19 Hotspot Counties - United States, March 8-July

575 15, 2020. MMWR Morb Mortal Wkly Rep. 2020;69(33):1127-32. Epub 2020/08/21. doi:

576

577

578

579

medicine. 2020;382(26):2534-43. Epub 2020/05/28. doi: 10.1056/NEJMsa2011686. PubMed PMID: 32459916; PubMed Central PMCID: PMCPMC7269015.

37. Karaca-Mandic P, Georgiou A, Sen S. Assessment of COVID-19 Hospitalizations by Race/Ethnicity in 12 States. JAMA Intern Med. 2021;181(1):131-4. Epub 2020/08/18. doi: 10.1001/jamainternmed.2020.3857. PubMed PMID: 32804192; PubMed Central PMCID: PMCPMC7432276 the University of Minnesota, Office of Academic Clinical Affairs and grants from United Health Foundation during the conduct of the study; personal fees from Tactile Medical, Precision Health Economics, and Sempre Health; and grants from the Agency for Healthcare Research and Quality, American Cancer Society, National Institute for Health Care Management, National Institute on Drug Abuse, and National Institutes of Health outside the submitted work. Dr Georgiou reported receiving personal fees from HealthGrades outside the submitted work. No other disclosures were

10.15585/mmwr.mm6933e2. PubMed PMID: 32817606; PubMed Central PMCID: PMCPMC7439980.

39. Evelyn B, Toigo T, Banks D, Pohl D, Gray K, Robins B, et al. Participation of 79 racial/ethnic groups in clinical trials and race-related labeling: a review of new molecular 
medRxiv preprint doi: https://doi.org/10.1101/2021.04.08.21255115; this version posted April 11, 2021. The copyright holder for this preprint (which was not certified by peer review) is the author/funder, who has granted medRxiv a license to display the preprint in perpetuity. All rights reserved. No reuse allowed without permission.

580 entities approved 1995-1999. J Natl Med Assoc. 2001;93(12 Suppl):18s-24s. Epub 581 2002/01/19. PubMed PMID: 11798060; PubMed Central PMCID: PMCPMC2719997.

582 40. Seidler EM, Keshaviah A, Brown C, Wood E, Granick L, Kimball AB. Geographic 583 distribution of clinical trials may lead to inequities in access. Clin Invest. 2014;4(4):37358480.

41. Administration UFaD. CLINICAL MEMORANDUM - COVID-19 Convalescent 586 Plasma Silver Spring2020. Available from: https://www.fda.gov/media/141480/download.

587 42. Beigel JH, Tomashek KM, Dodd LE, Mehta AK, Zingman BS, Kalil AC, et al. 588 Remdesivir for the Treatment of Covid-19 - Final Report. $\mathrm{N}$ Engl J Med. 589 2020;383(19):1813-26. Epub 2020/05/24. doi: 10.1056/NEJMoa2007764. PubMed 590 PMID: 32445440; PubMed Central PMCID: PMCPMC7262788.

591 43. Rojek AM, Horby PW. Modernising epidemic science: enabling patient-centred 592 research during epidemics. BMC Med. 2016;14(1):212. Epub 2016/12/19. doi: 593 10.1186/s12916-016-0760-x. PubMed PMID: 27989237; PubMed Central PMCID: 594 PMCPMC5165716. 
medRxiv preprint doi: https://doi.org/10.1101/2021.04.08.21255115; this version posted April 11, 2021. The copyright holder for this preprint (which was not certified by peer review) is the author/funder, who has granted medRxiv a license to display the preprint in perpetuity.

All rights reserved. No reuse allowed without permission.

597 Supplemental Table 1. Characteristics of acute care facilities and hospitals that enrolled patients 598 with COVID-19 in the US Expanded Access Program to convalescent plasma.

\begin{tabular}{|c|c|}
\hline Site Overview & \\
\hline & Overall \\
\hline Part of a Health System & $1,803 / 2,194(82.2)$ \\
\hline \multicolumn{2}{|l|}{ Micro/Metropolitan } \\
\hline Metropolitan & $1,918 / 2,232(85.9)$ \\
\hline Micropolitan & $244 / 2,232(10.9)$ \\
\hline None & $70 / 2,232(3.1)$ \\
\hline Urban/Rural Classification & $1,494 / 2,100(71.1)$ \\
\hline Sole Community Hospital & 199/2,194 (9.1) \\
\hline Rural Referral Center & $351 / 2,194(16.0)$ \\
\hline Teaching Hospital & $1,024 / 2,061(49.7)$ \\
\hline Major Teaching Hospital (member of COTH) & $447 / 2,061(21.7)$ \\
\hline University Affiliated & $1,062 / 2,194(48.4)$ \\
\hline
\end{tabular}


medRxiv preprint doi: https://doi.org/10.1101/2021.04.08.21255115; this version posted April 11, 2021. The copyright holder for this preprint (which was not certified by peer review) is the author/funder, who has granted medRxiv a license to display the preprint in perpetuity.

All rights reserved. No reuse allowed without permission.

601 Supplemental Table 2. Pre-existing conditions and cardiovascular and lung disease history of 602 patients with COVID-19 who enrolled in the US Expanded Access Program to convalescent 603 plasma.

\begin{tabular}{|c|c|}
\hline Pre-Existing Conditions & \\
\hline & Overall \\
\hline \multicolumn{2}{|l|}{ Pre-Existing Conditions } \\
\hline History of lung disease (ex. COPD, lung cancer) & $7,225 / 44,081(16.4)$ \\
\hline Cancer other than above & $2,068 / 44,081(4.7)$ \\
\hline History of cardiovascular conditions & $21,673 / 44,081(49.2)$ \\
\hline Obesity & $14,608 / 44,081(33.1)$ \\
\hline HIV positive & $351 / 44,081(0.8)$ \\
\hline HCV positive (Hepatitis C) & $375 / 44,081(0.9)$ \\
\hline On immunosuppressive therapy & $1,631 / 44,081(3.7)$ \\
\hline Diabetes & $17,612 / 44,081(40.0)$ \\
\hline \multicolumn{2}{|l|}{ History of Cardiovascular Disease } \\
\hline Stroke & $1,493 / 19,490(7.7)$ \\
\hline Coronary Artery Disease (including prior myocardial infarct or MI) & $4,019 / 19,490(20.6)$ \\
\hline Valvular Heart Disease & $501 / 19,490(2.6)$ \\
\hline Peripheral Vascular Disease & $702 / 19,490(3.6)$ \\
\hline Hypertension & $16,894 / 19,490(86.7)$ \\
\hline Arrhythmias & $2,199 / 19,490(11.3)$ \\
\hline Heart Failure & $2,413 / 19,490(12.4)$ \\
\hline Myocarditis & $15 / 19,490(0.1)$ \\
\hline Cardiomyopathy & $586 / 19,490(3.0)$ \\
\hline Prior Coronary Artery Bypass Graft (CABG) & $688 / 19,490(3.5)$ \\
\hline Other & $1,959 / 19,490(10.1)$ \\
\hline None & $130 / 19,490(0.7)$ \\
\hline \multicolumn{2}{|l|}{ History of Lung Disease } \\
\hline COPD (chronic bronchitis, emphysema) & $2,403 / 21,193(11.3)$ \\
\hline Lung cancer & $160 / 21,193(0.8)$ \\
\hline Asthma & $1,301 / 21,193(6.1)$ \\
\hline None & $112 / 21,193(0.5)$ \\
\hline Other lung-related conditions & $744 / 21,193(3.5)$ \\
\hline
\end{tabular}

604 